\title{
Characterization of 13 multi-drug resistant Salmonella serovars from different broiler chickens associated with those of human isolates
}

\author{
Lan-Ho Chiu', Cheng-Hsun Chiư ${ }^{2,3}$, Yan-Ming Horn ${ }^{4}$, Chien-Shun Chiou ${ }^{5}$, Chien-Yu Lee ${ }^{1}$, Chia-Ming Yeh ${ }^{4}$, \\ Chang-You Yu ${ }^{6}$, Chean-Ping $\mathrm{Wu}^{4}$, Chao-Chin Chang ${ }^{7}$, Chishih $\mathrm{Chu}^{8^{*}}$
}

\begin{abstract}
Background: Salmonella are frequently isolated from chickens and their products. Prevalent serogroups and serovars of Salmonella as well as their genotypes and antibiograms were determined for cloacal samples from 1595 chickens. To understand the possible serovar and $\mathrm{H}$ antigens for transmission between chicken and human, serovars and their $\mathrm{H}$ antigens of 164 chicken and 5314 human isolates were compared.

Results: Prevalence of Salmonella differed among chicken lines and ages. Chicken and human isolates belonged mainly to serogroup B, C1, C2-C3, D, and E. 13 serovars and 66 serovars were identified for chicken and human isolates respectively. The common serovars for chicken and human isolates were $S$. Typhimurium, $S$. Enteritidis, S. Albany, S. Derby, and S. Anatum and shared common H1 antigens "g complex; i; e,h; and z4,z24" and H2 antigens "1 complex and -". In human isolates, $\mathrm{H} 1$ antigen "i" and $\mathrm{H} 2$ antigen "-" were common in all serogroups. In chicken, antimicrobial susceptibility differed among serogroups, serovars and three counties. All isolates were susceptible to cefazolin and ceftriaxone, but highly resistant to ampicillin, chloramphenicol, flumequine, streptomycin, sulfamethoxazole-trimethoprim, and tetracycline. Except those isolates of serogroup C1 of Chick group and serogroup G, all isolates were multi-drug resistance. Only S. Kubacha, S. Typhimurium, S. Grampian, and S. Mons were resistant to ciprofloxacin and/or enrofloxacin.
\end{abstract}

Conclusion: In chicken, prevalent serogroups and serovars were associated with chicken ages, lines and regions; and flouroquinolone-resistant and MDR isolates emerged. $\mathrm{H} 1$ antigens " $\mathrm{g}$ complex and $\mathrm{i}$ " and $\mathrm{H} 2$ antigens

"1 complex and -" might be important for transmission of Salmonella between chicken and human.

\section{Background}

$S$. Enteritidis and $S$. Typhimurium, as two main zoonotic and broad-host-range pathogens that cause human salmonellosis, have been frequently isolated from poultry and their products [1-8]. Prevalence of Salmonella differs between layers and broilers $[9,10]$. Factors influencing the prevalence of chicken-associated Salmonella are feeds and growth environment [11], transportation process $[12,13]$, and chick sources [14]. Moreover, age-associated prevalence has been reported in layers, maximal prevalence at 18 weeks before egg production and gradually decreases with aging [15]. In broiler the

\footnotetext{
* Correspondence: cschu@mail.ncyu.edu.tw

${ }^{8}$ Department of Microbiology and Immunology, National Chiayi University, No 300, University Rd, Chiayi, 60004, Taiwan
}

prevalence differed depending on sale sites from $17.9 \%$ in slaughterhouses [16] and up to nearly $100 \%$ in the open markets and supermarkets [17].

Appearance of monophasic variants such as in $S$. Typhimurium $[4,5,12: 1:-][18,19]$ increases the problem in serotyping. Therefore, molecular methods have been developed to differentiate the serovars based on the nucleotide sequence variations in flagellar structural genes $f l i C$ and $f l j B$ [20-22] and PFGE analysis [15,23,24]. Prevalent serovars differ between chickens and ducks [25] and are associated with chicken lines and geographic area [15,25-27]. In Taiwan, we reported that Salmonella serogroup C1 and B, especially $S$. Typhimurium, were predominant Salmonella in duck and geese $[7,8]$. In another study of duck, the prevalence of Salmonella was $4.6 \%$ and S. Potsdam, S. Dusseldorf, and 
$S$. Indiana were the predominant serovars [28]. Therefore, we analyzed the prevalence of Salmonellae among different chicken sources and determined serotypes by PFGE analysis first, followed by traditional agglutination test of each genotype. After characterizing antibiograms and genomic variations in chromosome and plasmid of chicken isolates, flagellar antigens of chicken and human isolates were compared to understand the common antigens possibly for transmission of Salmonella between human and chicken.

\section{Methods}

\section{Sample collection and enrichment}

Totally 1595 chickens of 1 -year-old broiler breeder, 1-day-old chicks (Chick) and 9-week-old chickens (NHC) of Taiwan broiler chicken, 1-year-old layers and 3 -week-old broiler were sampled by 108C Amies Agar Gel - Single plastic swab (Copan Diagnostic Inc. Murrieta CA 92562 USA) from cloaca of each chicken fed at different farms in Chiayi of Taiwan from 2002 to 2003. Layers and broilers were fed in commercial cage and house farm respectively. The sampled swabs were grown in $9 \mathrm{~mL}$ of gram-negative broth (GN, Difco 0486) at $37^{\circ}$ $\mathrm{C}$ for $24 \mathrm{~h}$. Over-night $\mathrm{GN}$ bacterial broth was streaked on xylose lysine deoxycholate (XLD, Difco 0788) plates, which were incubated at $37^{\circ} \mathrm{C}$ for $24 \mathrm{~h}$. Black colonies were further examined by biochemical tests including triple sugar iron agar (TSI), Christensen's urea agar (URE), Simmons' citrate agar (CIT), sulfide-indole-motility medium (SIM), Voges-Proskauer medium (VP), Moller's ornithine decarboxylase medium (ORN), lysine iron agar (LIA) and mobility-indole-ornithine agar (MIO) purchased from Merck (Taiwan). At least two positive isolates from each plate were maintained on brain heart infusion agar (BHIA). In addition, Salmonellae from 9-week-old NHC in Tainan (36 isolates) and Pintung (30 isolates) at same period were also analyzed.

\section{Serogroup and serotype identification}

Salmonella-positive isolates were further serogrouped by the slide agglutination test with the use of $\mathrm{O}$-antigen antiserum and serotyped by the tube agglutination test with the use of $\mathrm{H}$-antigen antisera. Both antisera were purchased from Difco (Becton Dickinson Co., Franklin Lakes, NJ, USA). In addition, 5314 Salmonellae were collected from 19 medical centers and district hospitals located throughout the countries from 2003 to 2005 and serotyped in the Salmonella Reference Laboratory of Centers for Disease Control (CDC), Department of Health, Taiwan, with antisera purchased from S\&A Reagents Lab (Bangkok, Thailand), Denka Seiken (Tokyo, Japan), Statens Serum Institut (Copenhagen, Denmark), and a local biotech company, LTK Biolaboratories (Taoyuan, Taiwan). Phase induction was performed using a paper-bridged method developed in the laboratory of Taiwan CDC [29].

\section{Antimicrobial susceptibility test}

Each isolate was examined by disk diffusion method for its susceptibility to the antimicrobial agents including ampicillin (A, $10 \mu \mathrm{g})$, cefazolin $(\mathrm{CZ}, 30 \mu \mathrm{g})$, ceftriaxone (Cro, $30 \mu \mathrm{g}$ ), chloramphenicol (C. $30 \mu \mathrm{g})$, streptomycin $(\mathrm{S}, 10 \mu \mathrm{g})$, sulfamethoxazole-trimethoprium (Sxt, 1.25/ $23.75 \mu \mathrm{g})$, and tetracycline $(\mathrm{T}, 30 \mu \mathrm{g})$. In addition, resistance to three fluoroquinolones: flumequine ( $\mathrm{Ub}, 30 \mu \mathrm{g}$ ) of limited spectrum quinolone and enrofloxacin (En, $5 \mu \mathrm{g})$ as well as ciprofloxacin $(\mathrm{Ci}, 5 \mu \mathrm{g})$ of broad spectrum quinolone. While single bacterial colony was taken into $5 \mathrm{ml}$ of Mueller-Hinton broth (MHB; Merck, Taiwan) and cultured at $37^{\circ} \mathrm{C}$ for $8 \mathrm{hrs}$, bacterial broth was then adjusted to 0.5 Mcfarland and plated on MuellerHinton agar (MHA; Merck, Taiwan). Antimicrobial disks (BD Diagnostic systems, USA) were plated onto MHA agar and then incubated at $37^{\circ} \mathrm{C}$ for $18 \mathrm{hrs}$. Susceptibility and resistance were determined according to the interpretation criteria to E. coli (ATCC No. 25922) established by Clinical Laboratory Standards Institute (CLSI) standard [30]. Multi-drug resistance (MDR) isolate is defined as that isolate resistance to two or more antibiotics belonging to different antibiotic classes.

\section{Plasmid and genotype analysis}

Plasmid DNA pattern was determined by Kado and Liu method [31] and purified plasmid DNA was subjected to gel electrophoresis with $0.6 \%$ SeaKem GTG agarose (Cambrex Bio Science Rockland, Inc, Rockland, ME, USA) at $50 \mathrm{~V}$ for $2.5 \mathrm{hrs}$. Genotypes of all isolates were determined by PFGE analysis with restriction endonuclease $\mathrm{XbaI}$ digestion. The procedure of PFGE analysis was described earlier [32]. The digested DNA was separated by CHEF Mapper XA system (BioRad, Hercules, California, USA) in $0.5 \times \mathrm{TBE}$ at $14^{\circ} \mathrm{C}$ for $22 \mathrm{~h}$ with Auto-Algorithm model of 30-600 kb, $6 \mathrm{~V} / \mathrm{cm}$, switching interval 4.0-70.0 sec. The genotypes were defined as 3 band differences between two isolates [33].

\section{Results}

\section{Prevalent serogroups and serovars among chicken lines} and locations

Prevalence of Salmonella differed between chicken lines ( $0 \%$ for layer vs $0.3 \%$ for breeder broiler and $11.3 \%$ for broiler) and ages from $10.3 \%$ for Chick and $3.8 \%$ for NHC of Taiwan broiler chicken (Table 1). 164 Salmonella isolates belonged to serogroup $\mathrm{C} 1, \mathrm{~B}, \mathrm{D}, \mathrm{C} 2-\mathrm{C} 3$, E, and $G$ in the decreasing order and the number of serogroups differed among 3 counties. Further, region-specific serogroups were identified as serogroup $\mathrm{G}$ in Chiayi, serogroup D in Tainan, and serogroup C2-C3 
Table 1 Prevalence of Salmonella serogroups in different layer- and broiler chickens in three Counties

\begin{tabular}{|c|c|c|c|c|c|c|c|c|c|}
\hline \multirow{3}{*}{ Serogroup } & \multicolumn{8}{|c|}{ County $^{\mathrm{a}}$} & \multirow{3}{*}{ Total isolates } \\
\hline & \multicolumn{6}{|c|}{ Chiayi } & \multirow{2}{*}{$\frac{\text { Tainan }}{\text { NHC }}$} & \multirow{2}{*}{$\begin{array}{c}\text { Pintung } \\
\text { NHC }\end{array}$} & \\
\hline & Layer & Breeder & Broiler & $\mathrm{NHC}^{\mathrm{b}}$ & Chick $^{c}$ & Total & & & \\
\hline$B$ & 0 & 1 & 16 & 2 & 0 & 19 & 13 & 7 & 39 \\
\hline $\mathrm{C} 1$ & 0 & 0 & 1 & 0 & 77 & 78 & 2 & 8 & 88 \\
\hline $\mathrm{C} 2$ & 0 & 0 & 0 & 0 & 0 & 0 & 0 & 11 & 11 \\
\hline $\mathrm{D}$ & 0 & 0 & 0 & 0 & 0 & 0 & 18 & 0 & 18 \\
\hline E & 0 & 0 & 0 & 0 & 0 & 0 & 0 & 5 & 5 \\
\hline G & 0 & 0 & 0 & 3 & 0 & 3 & 0 & 0 & 3 \\
\hline Total & 0 & 1 & 17 & 5 & 77 & 99 & 33 & 31 & 164 \\
\hline Prevalence & 0 & 0.3 & 11.3 & 3.8 & 10.3 & 6.2 & & & - \\
\hline (\%) & $(0 / 285)$ & $(1 / 280)$ & $(17 / 150)$ & $(5 / 130)$ & $(77 / 750)$ & (99/1595) & & & \\
\hline
\end{tabular}

a The number of each serogroup was determined in our laboratory by examination of Salmonella isolated from cloacal samples of chicken in Chiayi County and from surveillance of Tainan and Pintung County.

b NHC: 9-wk-old Native Hybrid Chickens (simulated native chicken) of Taiwan broiler chickens

c Chick: one-day-old NHC chicks.

and $\mathrm{E}$ in Pintung (Table 1). In Chiayi, age-associated serogroups were found for serogroup C1 Salmonella in Chick group and serogroup B and G in NHC group (Table 1).

164 Salmonella isolates were firstly examined for their genotypes by XbaI-PFGE analysis (Figure 1) and further isolates of each genotype were serotyped by traditional agglutination method. In total, 18 PFGE patterns belonged to 13 serovars (Table 2). Except $S$. Albany and $S$. Havana that consisted of multiple genotypes, PFGE genotypes matched exactly with serotypes. 13 serovars were $S$. Derby, $S$. Kubacha, $S$. Mons, and $S$. Typhimurium (containing $S$. Typhimurium var. Copenhagen) of serogroup B, S. Choleraesuis (containing non-typable serovar), S. Grampian, S. Hissar, and S. Redba of serogroup C1, $S$. Albany and $S$. Blockley of serogroup C2-C3, S. Enteritidis of serogroup D, S. Anatum of serogroup E and $S$. Havana of serogroup G (Table 2). Predominant serovar in each serogroup was $S$. Mons, not $S$. Typhimurium, in serogroup B, $S$. Choleraesuis from

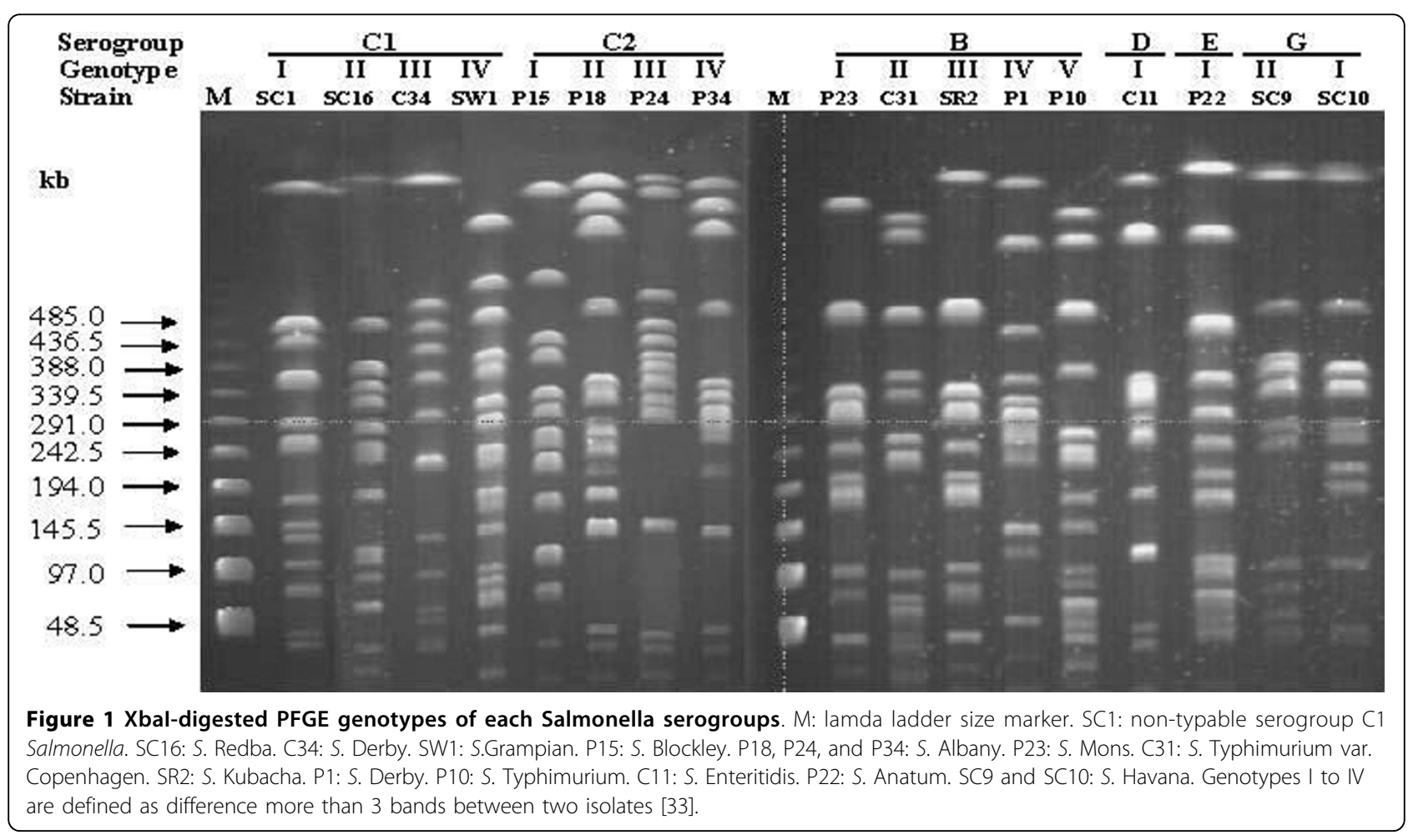


Table 2 Characterization of Salmonella isolates by 4 methods

\begin{tabular}{|c|c|c|c|c|c|c|c|}
\hline Serogroup & Serovar & County & Chicken lines & Resistance type ${ }^{a}$ & PFGE genotype ${ }^{b}$ & Plasmid type $^{c}$ & Total isolates \\
\hline & Derby & Pintung & $\mathrm{NHC}$ & $E$ & IV & 5 & 1 \\
\hline & & Pintung & $\mathrm{NHC}$ & M & IIIa & $2 \mathrm{a}$ & 2 \\
\hline & Kubacha & Chiayi & $\begin{array}{l}\mathrm{NHC} \\
\text { Broiler }\end{array}$ & $J$ & IIIa & $\begin{array}{c}4 a \\
1\end{array}$ & $\begin{array}{l}1 \\
1\end{array}$ \\
\hline & & & Broiler & j & I & 1 & $\begin{array}{c}12 \\
3\end{array}$ \\
\hline & & Chiayi & $\mathrm{NHC}$ & K & Id & $1 \mathrm{a}$ & 1 \\
\hline & & & Breeder & C & I e & $2 b$ & 1 \\
\hline & & Pintung & $\mathrm{NHC}$ & G & I & $1 \mathrm{~b}$ & 1 \\
\hline \multirow[t]{11}{*}{ B } & Mons & & & & I & 2 & 4 \\
\hline & & & & & & $1 b$ & 2 \\
\hline & & & & J & $\mathrm{I} a$ & $1 \mathrm{a}$ & 2 \\
\hline & & Tainan & $\mathrm{NHC}$ & & I & 3 & 1 \\
\hline & & & & & & $1 d$ & 1 \\
\hline & & & & & & $1 c$ & 1 \\
\hline & & & & K & la & $1 b$ & 1 \\
\hline & Typhimurium var. Copenhagen & Tainan & $\mathrm{NHC}$ & $\mathrm{L}$ & $\|$ & 4 & $\begin{array}{l}1 \\
1\end{array}$ \\
\hline & Typhimurium & Pintung & $\mathrm{NHC}$ & $\begin{array}{l}M \\
D\end{array}$ & $\mathrm{~V}$ & $\begin{array}{c}3 a \\
6\end{array}$ & $\begin{array}{l}2 \\
1\end{array}$ \\
\hline & Choleraesuis & Chiayi & Chick & A & $\begin{array}{l}\text { III } \\
\text { IIla } \\
\|\| \mathrm{b}\end{array}$ & $\begin{array}{l}1 \\
5\end{array}$ & $\begin{array}{c}59 \\
1 \\
1\end{array}$ \\
\hline & & Tainan & & G & & 3 & 1 \\
\hline \multirow[t]{7}{*}{$\mathrm{C} 1$} & Grampian & & $\mathrm{NHC}$ & & IV & $1 a$ & 1 \\
\hline & & Pintung & & M & & 1 & 7 \\
\hline & & & & & & $1 a$ & 1 \\
\hline & Hissar & Chiayi & Broiler & 1 & V & 4 & 1 \\
\hline & $N T^{d}$ & Chiayi & Chick & A & I & $\begin{array}{l}1 \\
2\end{array}$ & $\begin{array}{c}5 \\
10\end{array}$ \\
\hline & Redba & Chiayi & Chick & A & $\|$ & 5 & 1 \\
\hline & Blockley & Pintung & $\mathrm{NHC}$ & $E$ & I & 1 & 1 \\
\hline \multirow[t]{4}{*}{$\mathrm{C} 2$} & & & & & $\|$ & & 3 \\
\hline & Albany & Pintung & $\mathrm{NHC}$ & J & III & 1 & 5 \\
\hline & & & & & IV & & 2 \\
\hline & & & & $\mathrm{F}$ & & 2 & 7 \\
\hline \multirow[t]{3}{*}{ D } & Enteritidis & Tainan & $\mathrm{NHC}$ & & I & 3 & 3 \\
\hline & & & & & & 1 & 7 \\
\hline & & & & B & & 2 & 1 \\
\hline \multirow[t]{2}{*}{$E$} & Anatum & Pintung & $\mathrm{NHC}$ & J & 1 & 1 & 3 \\
\hline & & & & $\mathrm{H}$ & & 2 & 1 \\
\hline G & Havana & Chiayi & $\mathrm{NHC}$ & A & I & 1 & $\begin{array}{l}2 \\
1\end{array}$ \\
\hline
\end{tabular}

${ }^{a}$ Antibiogram of each isolate was determined by the resistance to antimicrobials ampicillin (A), chloramphenicol (C), ciprofloxacin (Ci), ceftriaxone (Cr), cefazolin $(C z)$, enrofloxacin $(E n)$, flumequine $(U b)$, streptomycin $(S)$, sulfamethoxazole-trimethopriem $(S x t)$, tetracycline $(T)$. The association of resistance type with antibiogram was the followings: resistance type A for antibiogram S, B for Ub, C for UbS, D for ST, E for SxtUb, F for CSTUb, G for ASSxtTUb, H for ACSSxtT, I for CSSxtTUb, J for ACSSxtTUb, K for ACEnSSxtTUb, L for ACCiEnSxtTUb, and M for ACCiEnSSxtTUb.

${ }^{\mathrm{b}} \mathrm{PFGE}$ genotypes was determined by 3 band differences between two isolates [Figure 1, [32]].

'Plasmid was analyzed by Kado and Liu method (30, supplementary Figure 1). Plasmid profile was determined by plasmid size and number (supplementary Table 2).

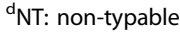


Chick and $S$. Grampian from NHC in serogroup $\mathrm{C} 1$, and $S$. Albany in serogroup C2-C3 (Table 2).

\section{Antimicrobial susceptibility}

All isolates were susceptible to $\mathrm{CZ}$ and Cro. In contrast to resistance only to streptomycin for $77 \mathrm{~S}$. Choleraesuis isolates in Chick group and two isolates of serogroup G, all isolates were MDR (Table 3). Serogroup B, C2-C3 and $\mathrm{E}$ were highly resistance to $\mathrm{A}, \mathrm{C}, \mathrm{S}, \mathrm{Sxt}, \mathrm{T}$ and $\mathrm{Ub}$. However, serogroup D was relatively low in resistance to above antimicrobials. Serogroup and serovars isolated from broiler and NHC group differed in resistance to three quinolone antimicrobials. Except serogroups E and G, all serogroups, were nearly $100 \%$ resistance to Ub and only serogroups $\mathrm{B}$ and $\mathrm{C} 1$ were resistant to $\mathrm{En}$ and Ci (Table 3). Among 164 isolates, we only found 4 Enresistant $S$. Mons and $13 \mathrm{En}$ and $\mathrm{Ci}$-resistant isolates including $2 S$. Kubacha isolates, $2 S$. Typhimurium isolates, and $1 S$. Typhimurium var. Copenhagen isolates of serogroup B and $8 \mathrm{~S}$. Grampian isolates of serogroup C1 (Table 2). Importantly, near $40 \%$ of isolates from Pintaung were resistant to En and Ci. According to resistance to 9 antimicrobials tested, 13 antibiograms differed among serogroups and serovars (Table 2 and 3 ). Highest drug-resistant types $\mathrm{L}$ with antibiogram ACCiEnSxtTUb and $M$ with antibiogram ACCiEnSSxtTUb were only found in serogroup B and C1 of NHC group from Pintung mostly and Tainan. Salmonella genomic island (SGI) related ACSSuT resistance was found in serogroup B, C2 and E. Resistance to antimicrobials tested varied among 3 counties (Table 3 and Additional file 1: Table S1). Highest resistance was found in isolates from Pintung, followed by Tainan, and Chiayi and lowest Sxt resistance rate was observed in isolates from Tainan.

\section{Plasmid profile analysis}

Based on plasmid number and size determined by gel electrophoresis and plasmid size marker $50 \mathrm{~kb}$ and
$90 \mathrm{~kb}$ of OU7526, in total 19 plasmid profiles were identified and the plasmid profiles and their number differed among serogroups and serovars (Additional file 2: Table S2; Additional file 3: Figure S1). Among 13 serovars, $S$. Albany, $S$. Blockley, $S$. Havana, and $S$. Redba as well as few isolates of $S$. Choleraesuis, $S$. Enteritidis, and $S$. Typhimurium lacked plasmid. All other serovars harbored at least one plasmid and differed in plasmid profile.

\section{Serovar association between chicken and human isolates}

$S$. Albany, $S$. Anatum, S. Choleraesuis, S. Derby, $S$. Enteritidis, and $S$. Typhimurium were in common for 13 chicken serovars and 66 human serovars and other 7 serovars of chicken isolates were not or barely observed in human (Table 2, 4 and 5). Total serovar number of each serogroup decreased from serogroup C1, B, C2, E to $\mathrm{D}$ for human isolates (Table 4). Despite of the presence of 66 serovars, there were only presence of $11 \mathrm{H} 1$ antigens including b, c, d, j, k, r, y, eh, g-complex, and z-complex and $5 \mathrm{H} 2$ antigens including -, $\mathrm{z}_{6}$, lw, 1-complex, and en-complex (Table 4). Common antigens in all serogroups were "i" for $\mathrm{H} 1$ antigen: and "-" for $\mathrm{H} 2$ antigen. In compared the chicken and human isolates from Taiwan, United Kingdom and United States, the common serovars were $S$. Typhimurium, $S$. Enteritidis, $S$. Anatum, and $S$. Derby with common antigens of . "g complex; i; $\mathrm{z}_{4}, \mathrm{z}_{24}$; and e,h" for H1 antigen and "- and 1 complex" for $\mathrm{H} 2$ antigen (Table 5).

\section{Discussion}

As one of main pathogen to cause foodborne diseases, Salmonella has been frequently reported among different animal sources, especially more divergent Salmonella serovars found in chickens [34]. With the limited serovars in 164 chicken isolates, serogroups C2, D, E and $\mathrm{G}$ were restricted in one county and serogroup $\mathrm{B}$ and $C 1$ were found in all three counties (Table 2), suggesting possibly that serogroup $\mathrm{B}$ and $\mathrm{C} 1$ isolates may

Table 3 Differences in prevalence of resistance to 9 antimicrobials among serogroups and Counties

\begin{tabular}{|c|c|c|c|c|c|c|c|c|c|}
\hline \multirow[t]{2}{*}{ Antimicrobials $^{a}$} & \multicolumn{6}{|c|}{ Serogroup (\%) } & \multicolumn{3}{|c|}{ County (\%\%) } \\
\hline & B & $\mathrm{C} 1$ & $\mathrm{C} 2$ & D & $E$ & G & Chiayi & Tainan & Pintung \\
\hline$A$ & 61.5 & 11.4 & 100 & 0 & 100 & 0 & 23.8 & 47.1 & 77.4 \\
\hline$C$ & 89.7 & 10.2 & 91 & 0 & 100 & 0 & 90.5 & 70.6 & 74.2 \\
\hline $\mathrm{Ci}$ & 12.8 & 9.1 & 0 & 0 & 0 & 0 & 0 & 2.9 & 38.7 \\
\hline En & 20.5 & 9.1 & 0 & 0 & 0 & 0 & 4.7 & 8.8 & 38.7 \\
\hline S & 97.4 & 100 & 91 & 55.6 & 100 & 100 & 100 & 76.5 & 93.5 \\
\hline Sxt & 94.9 & 12.5 & 91 & 0 & 100 & 0 & 85.7 & 47.1 & 96.8 \\
\hline T & 94.9 & 12.5 & 91 & 55.6 & 100 & 0 & 85.7 & 76.5 & 93.5 \\
\hline $\mathrm{Ub}$ & 97.4 & 12.5 & 91 & 100 & 60 & 0 & 90.5 & 100 & 90.3 \\
\hline
\end{tabular}

a A for ampicillin, C for chloramphenicol, Ci for ciprofloxacin, En for enrofloxacin, $\mathrm{S}$ for streptomycin, Sxt for sulfamethoxazole-trimethoprime, $\mathrm{T}$ for tetracycline, and $\mathrm{Ub}$ for $\mathrm{Ub}$ for flumequine. 
Table 4 The H1 and H2 antigens of 66 Salmonella serovars of human isolates collected from 2003 to 2005

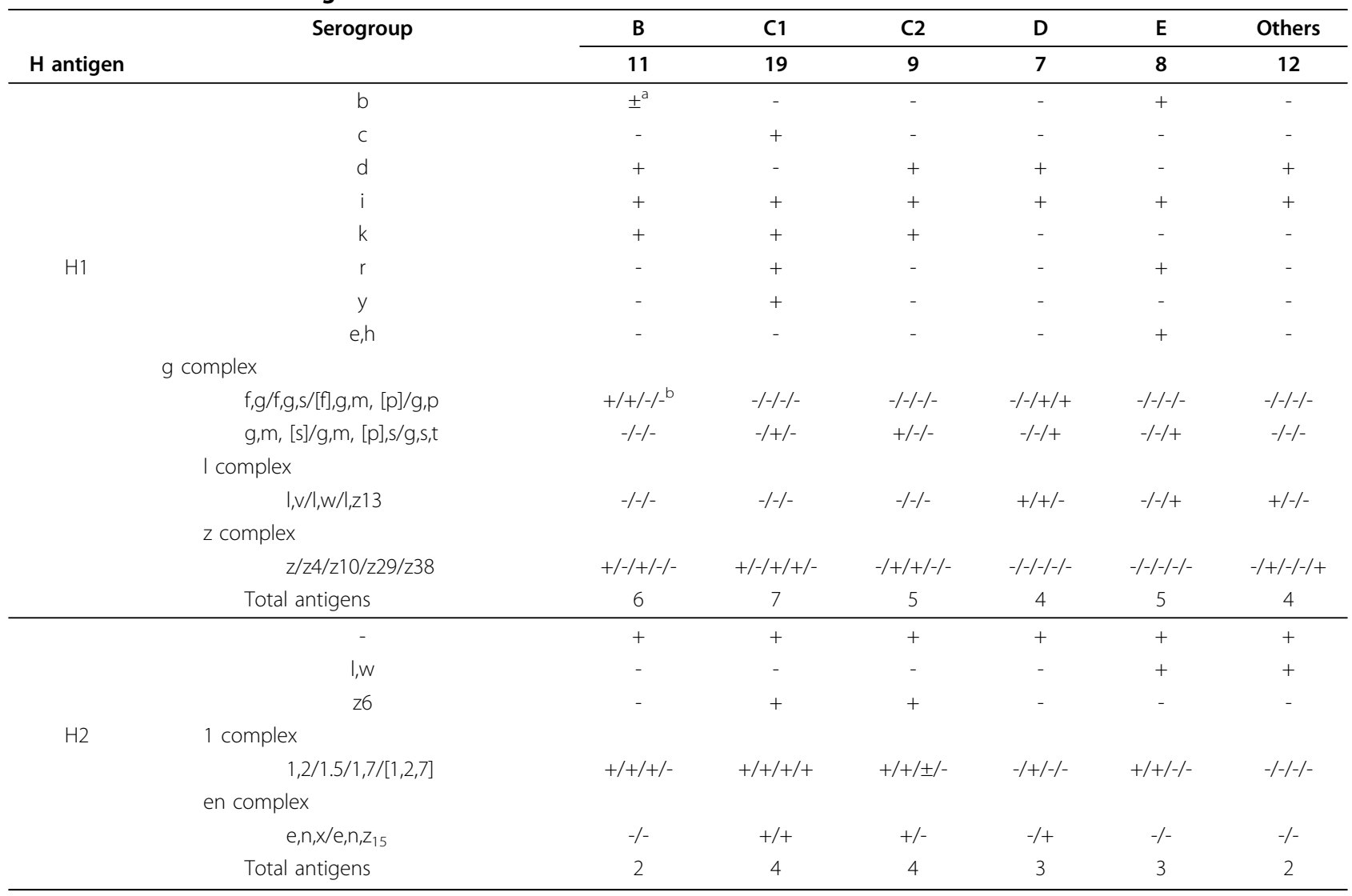

${ }^{\mathrm{a}} \pm$ means presence $(+)$ or absence $(-)$ of $\mathrm{b}$ antigen.

${ }^{b}+/+/-/-$ indicates presence $(+)$ of antigens $f, g / f, g, s$ and absence $(-)$ of antigens $[f], g, m,[p] / g$,

be more adapted to chicken. In human isolates, we found that the serovar number in each serogroup were not associated positively with the serogroup prevalence, such as highest serovar number in low prevalent serogroup $\mathrm{C} 1$ vs lower serovar number in high prevalent serogroup B and serogroup D (Table 4). These results imply that serogroup $\mathrm{C} 1$ may occasionally infect human isolates. Further, serovars are determined by flagellins: $\mathrm{H} 1$ and $\mathrm{H} 2$ antigens encoded by $f l i C$ and $f l j B$. As one of the most important immunogens, flagellin interacts with the toll-like receptor 5 (TLR5) to activate $\mathrm{NF} \kappa \mathrm{B}$ pathway and proinflammatory genes to regulate innate and adaptive immune system [35-38]. However, aflagellar serovars $S$. Pullorum and $S$. Gallinarum cause more severe infection than flagellar serovars in chicken because of aflagellar $S$. Typhimurium could avoid the TLR5 regulation of IL-1 $\beta$ expression and polymorphonuclear cell infiltration in gut [39]. Such evasion of TLR5 is critical for survival of flagellar bacteria at muscos [40]. [In the present study, we found that $\mathrm{i}$ of $\mathrm{H} 1$ antigen and lack of $\mathrm{H} 2$ antigen were the common antigens for all serogroups in human isolates (Table 4). However, in comparing 13 chicken serovars and 66 human serovars of this study with serovars of chicken and human isolates from UK and USA, only $S$. Enteritidis, $S$. Typhimurium, $S$. Albany, $S$. Derby, $S$. Anatum and $S$. Havana were common in both hosts (Table 5). However, these serovars shares same antigens: g complex; $\mathrm{i}$; and $\mathrm{z}_{4}, \mathrm{z}_{24}$ of $\mathrm{H} 1$ antigen and 1 complex and - of $\mathrm{H} 2$ antigens (Table 5), implying these antigens may be important for Salmonella transmission between chicken and human.

Prevalent serogroups and serovars are related to chicken lines (Table 1)[9,10] and ages [15]. In layer, agerelated prevalence was reported earlier [15] and no Salmonella was isolated from 1-year-old layers in the present study (Table 1). Such age-associated clearance may be due to stronger antigen-specific $\mathrm{T}$-cell response in older chicken [41] and not related to B-cell response [42]. Age-related serovars were also identified in Taiwan broiler chickens (Table 2). Almost all isolates were $S$. Choleraesuis and non-typable Salmonella (possibly monophasic $S$. Choleraesuis) of serogroup C1 in Chick group and $S$. Mons of serogroup B in NHC group (Table 2). As swine-adapted pathogen, S. Cholearesuis has seldom reported from chicken. However, $S$. Choleraesuis in 1-day-old chicks may be contaminated from 
Table 5 Serovars of chicken isolates associated with those of human isolates collected from 2003 to 2005

\begin{tabular}{|c|c|c|c|c|c|c|c|c|c|c|c|c|c|c|}
\hline \multirow{4}{*}{$\begin{array}{l}\text { Serovars of } \\
\text { chicken isolates } \\
\text { in this study }\end{array}$} & & & \multicolumn{12}{|c|}{ Prevalence (\%) of serovar of chicken and human isolates from different area } \\
\hline & \multicolumn{2}{|c|}{$H$ antigen } & \multicolumn{4}{|c|}{2003} & \multicolumn{4}{|c|}{2004} & \multicolumn{4}{|c|}{2005} \\
\hline & \multirow[b]{2}{*}{1} & \multirow[b]{2}{*}{2} & \multicolumn{2}{|c|}{ Chicken } & \multicolumn{2}{|c|}{ Human } & \multicolumn{2}{|c|}{ Chicken } & \multicolumn{2}{|c|}{ Human } & \multicolumn{2}{|c|}{ Chicken } & \multicolumn{2}{|c|}{ Human } \\
\hline & & & $U A^{a}$ & UK $^{\mathbf{b}}$ & USA & $\mathrm{T}^{\mathrm{c}}$ & USA & UK & USA & 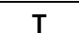 & USA & UK & USA & 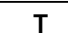 \\
\hline \multicolumn{15}{|l|}{ Serogroup B } \\
\hline Derby & $f, g$ & {$[1,2]$} & 0.2 & 0.3 & 0.3 & 2.4 & 0 & 0 & 3.8 & 2.7 & 0.03 & 0.2 & 0.34 & 2.3 \\
\hline Kubacha & $\mathrm{l}, \mathrm{z}_{13}, \mathrm{z}_{28}$ & 1,7 & 0 & 0 & 0 & 0 & 0 & 0 & 0 & 0 & 0 & 0 & 0 & 0 \\
\hline Mons & $d$ & $\mathrm{I}, \mathrm{W}$ & 0 & 0 & 0 & 0 & 0 & 0 & 0 & 0 & 0 & 0 & 0 & 0 \\
\hline Typhimurinum & $\mathrm{i}$ & $1,2,[7]$ & 4.7 & 2.8 & 15.8 & 25.2 & 6.7 & 1.7 & 16.5 & 22.3 & 318 & 1.4 & 16.5 & 24.7 \\
\hline \multicolumn{15}{|l|}{ Serogroup C1 } \\
\hline Choleraesuis & c & 1,5 & 0 & 0 & 0.03 & 4.2 & 0 & 0 & 0.05 & 4.3 & 0.03 & 0 & 0.02 & 2.0 \\
\hline Grampian & r & $\mathrm{l}, \mathrm{W}$ & 0 & 0 & 0 & 0 & 0 & 0 & 0 & 0 & 0 & 0 & 0 & 0 \\
\hline Hissar & c & 1,2 & 0 & 0 & 0 & 0 & 0 & 0 & 0 & 0 & 0 & 0 & 0 & 0 \\
\hline Redba & $z_{10}$ & $z_{35}$ & 0 & 0 & 0 & 0 & 0 & 0 & 0 & 0 & 0 & 0 & 0 & 0 \\
\hline \multicolumn{15}{|l|}{ Serogroup C2-C3 } \\
\hline Blockley & k & 1,5 & 0 & 0 & 0.18 & 0 & 0 & 0 & 0.23 & 0 & 0.05 & 0 & 0.14 & 0 \\
\hline Albany & $Z_{4,} Z_{24}$ & - & 0 & 0 & 0.05 & 4.7 & 0.6 & 0 & 0.09 & 3.4 & 0.03 & 0 & 0.10 & 4.9 \\
\hline \multicolumn{15}{|l|}{ Serogroup D1 } \\
\hline Enteritidis & {$[\mathrm{f}], \mathrm{g} \cdot \mathrm{m} .[\mathrm{p}]$} & {$[1,7]$} & 3.8 & 5.2 & 13.1 & 22.7 & 9.8 & 1.8 & 14.10 & 22.9 & 4.7 & 4.5 & 18.6 & 24.4 \\
\hline \multicolumn{15}{|l|}{ Serogroup E } \\
\hline Anatum & $\mathrm{e}, \mathrm{h}$ & 1,6: $\left[z_{64}\right]$ & 0.5 & 0.6 & 0.47 & 1.0 & 0 & 0 & 0.7 & 1.1 & 0.64 & 0.6 & 0.54 & 0.7 \\
\hline \multicolumn{15}{|l|}{ Serogroup G } \\
\hline Havana & $f, g,[s]$ & - & 0.2 & 1.2 & 0.08 & 0 & 0.6 & 0.7 & 0.089 & 0.1 & 0.27 & 0.8 & 0.07 & 0 \\
\hline Total & Salmonellae & & 2038 & 924 & 37442 & 529 & 164 & 717 & 35661 & 2557 & 3743 & 665 & 36214 & 2228 \\
\hline
\end{tabular}

adata from Salmonella Annual Summary for clinical Salmonella isolates from nonhuman and human sources reported to the Disease Control and Prevention (CDC) and the USDA National Veterinary Services Laboratory (NSVL), USA.

${ }^{b}$ data from Annual Report and Accounts 2008/2009 of Veterinary Laboratory Agency, Department of Environment, Food and Rural Affairs, United Kingdom.

'data from the Disease Control and Prevention (CDC), Taiwan.

the hatchery, particular from eggshell membrane; in which $S$. Typhimurium, not $S$. Choleraesuis, is main serovar [43]. If highly invasive $S$. Choleraesuis could infect chicks and use the chicken as reservoir, it will lead to a public problem of circulating such high invasive serovar in animals. In broiler, prevalence of Salmonella differed between chicken parts $(2.36 \%$ for legs and $4.25 \%$ for breasts of broiler) [19]. Further, prevalent serovars differ between sampling sources e.g. the $S$. Anatum and $S$. Rissen in chicken meat [44] and $S$. Blockley, $S$. Hadar and $S$. Bredeney in the cecal samples (24).

Several methods have been developed to differentiate clinical isolates. In this study, PFGE patterns almost matched serotypes, although $S$. Albany and $S$. Havana appeared multiple genotypes with highly similar banding patterns (Table 2). Therefore, PFGE typing is a useful tool to assist serotyping of Salmonella isolates before doing traditional serotypes [2,27]. In contrast to PFGE type, plasmid analysis is the most convenient method for subtyping $[15,45]$. In this study, plasmid variations were more diverse than genomic variations; however, $S$. Albany and $S$. Havana with highly genomic variations lacked plasmid (Table 2). These results may imply that recent evolution of Salmonella might be mainly through plasmid acquisition to introduce beneficial genes for host serovar to survival.

Antimicrobial susceptibility of Salmonella can be used to monitor drug abuse in different regions (Table 2) [46] and animal sources [44,47]. Early study reported that Salmonella from chicken, not from human, pig and cattle, was less resistance to A, C, and Sxt [47]. Nevertheless, resistance to $\mathrm{T}$ was frequently found in chicken isolates [48]. Since discovery of ACSSuT-resistant region in SGI of S. Typhimurium DT104 [49], variations within SGI and complex integron In104 change the antimicrobial resistance [50]. In this study, our chicken isolates were highly resistant to antimicrobials A, C, S, Sxt, T and Ub (Table 3). These results imply that $S$. Albany, $S$. Anatum, $S$. Grmpian, $S$. Hissar, $S$. Kubacha, $S$. Mons, and $S$. Typhimurium with resistance types from $\mathrm{H}$ to $\mathrm{M}$ may be derived from misuse of antimicrobials or due to presence of SGI and/or integron [51]. Mechanism to develop En and Ci resistance is due to mutation in quinolone-resistance determining region or expression of 
efflux pump [52]. Earlier, fluoroquinolone-resistant Salmonella was seldom reported in poultry's isolates worldwide $[10,44,47,48]$. Until recently, resistance to similar fluoroquinolones: En and $\mathrm{Ci}$ has been reported from chicken in Spain [16]. In contrast to same prevalence of resistance to $\mathrm{En}$ and $\mathrm{Ci}$ in swine and human isolates [32], we found that resistance rate to En was higher than that of $\mathrm{Ci}$ (Table 2). However, En and Ci resistant isolates were only found in few serovars of serogroups $\mathrm{B}$ and $\mathrm{C} 1$ and mainly in Pintung area (Table 3). These results indicate that possibly En was misuse in Pintung county to induce resistance in prevalent serovars.

\section{Conclusion}

13 chicken serovars were identified and differed in drug resistance and prevalence associated with chicken lines, ages and regions. Five serovars were common between these chicken serovars and 66 human serovars

Additional file 1: Table S1. Association of antibiograms with serogroups among three counties. Antibiograms differed among three counties and serogroups.

Additional file 2: Table S2. Plasmid profiles of serovars in each serogroup. Plasmid profiles determined by size and number was associated with serotypes.

Additional file 3: Figure S1. Representative plasmid profiles of Salmonella isolates collected from chickens. Plasmid size and number of each representative plasmid profile was determined by Kado-Liu method and standard plasmid size of $50 \mathrm{~kb}$ and $90 \mathrm{~kb}$ plasmid of OU7526.

\section{Abbreviations \\ A: ampicillin; BHIA: brain heart infusion agar; C: chloramphenicol; CDC: Center for Disease Control; Ci: ciprofloxacin; CIT: Simmons' citrate agar; Cro: ceftriaxone; CZ: cefazolin; En: enrofloxacin; GN: gram-negative broth; LIA: lysine iron agar; MDR: multi-drug resistance; MHA: Mueller-Hinton agar; MHB: Mueller-Hinton broth; MIO: mobility-indole-ornithine agar; NHC: native hybrid chicken; ORN: Moller's ornithine decarboxylase medium; PFGE: pulsed-field gel electrophoresis; S: streptomycin; SIM: sulfide-indole-kmotility medium; Sxt: sulfamethoxazole-trimethoprium; T: tetracycline; TSI: triple sugar iron agar; Ub: flumequine; URE: Christensen's urea agar; VP: Voges-Proskauer medium; XLD: xylose lysine deoxycholate agar.}

\section{Acknowledgements}

This work was funded by grants from Council of Agriculture under grant [97 AS-14.6.1-BQ-B4(9)] and National Science Council (NSC96-2314-B-415-001), Executive Yuan, Taiwan (CC).

\section{Author details}

'Animal Disease Control Center Chiayi County, Taibao 1st Rd., Taibao City, Chiayi County 612, Taiwan. ${ }^{2}$ Department of Pediatrics, Chang Gung Children's Hospital, 5 Fu-Hsing Street, Kuei-Shan Hsiang, 33375, Taoyuan, Taiwan. ${ }^{3}$ Department of Medicine, College of Medicine, Chang Gung University, 259 Wen-Hwa 1st Road, Kwei-Shan, Taoyuan, 33302, Taiwan. ${ }^{4}$ Department of Animal Science, National Chiayi University, No 300, University Rd, Chiayi, 60004, Taiwan. ${ }^{5}$ The Central Region Laboratory, Center of Research and Diagnostics, Centers for Disease Control, No 30, Wenxin S 3rd Rd, Nantun Dist, Taichung, 40856, Taiwan. ${ }^{6}$ Department of Veterinary Medicine, National Chiayi University, No 300, University Rd, Chiayi, 60004, Taiwan. ${ }^{7}$ Graduate Institute of Veterinary Public Health, School of Veterinary Medicine, National Chung Hsing University, 250, Kuo Kuang Road, Taichung
40200, Taiwan. ${ }^{8}$ Department of Microbiology and Immunology, National Chiayi University, No 300, University Rd, Chiayi, 60004, Taiwan.

\section{Authors' contributions}

CC designed, instructed and supervised most aspects of this project. LHC, CYL and CYY collected samples and data analysis of chicken isolates. LHC and CMY did laboratory work and data analysis. JML and SWC performed the experiments and data analysis. CHC and CSC assisted in the design of the study and data analysis of human isolates. CLC, CYY, and CCH gave useful comments and critically read the manuscript. YMH and CPW assisted in animal sampling, data analysis and edited the manuscript. All authors read and approved the final manuscript.

\section{Authors' information}

L-HC and C-YL are officials of Animal Disease Control Center ChiaYi County, Taiwan; C-HC is professor of Department of Pediatrics, Chang Gung Children's Hospital and Chang Gung University College of Medicine, Taoyuan, Taiwan; Y-MH and C-PW are professors of Department of Animal Science, National Chiayi University, Chiayi, Taiwan; C-MY was master graduate student of Department of Animal Science, National Chiayi University, Chiayi, Taiwan; C-SC is Chief Investigator of The Central Region Laboratory, Center of Research and Diagnostics, Centers for Disease Control, Taichung, Taiwan; C-YY is professor of Department of Veterinary Medicine, National Chiayi University, Chiayi, Taiwan; C-CC is associate professor of Graduate Institute of Veterinary Public Health, School of Veterinary Medicine, National Chung Hsing University, Taichung, Taiwan; CC is the chairman of Department of Microbiology and Immunology, National Chiayi University, Chiayi, Taiwan.

Received: 7 April 2009 Accepted: 23 March 2010

Published: 23 March 2010

\section{References}

1. al-Nakhli HM, al-Ogaily ZH, Nassar TJ: Representative Salmonella serovars isolated from poultry and poultry environments in Saudi Arabia. Rev SC Tech 1999, 18:700-709.

2. Berghold C, Kornschober C, Lederer L, Allerberger F: Occurrence of Salmonella Enteritidis phage type 29 in Austria: an opportunity to assess the relevance of chicken meat as source of human Salmonella infections. EuroSurveill 2004, 9:31-34.

3. Boonmar S, Bangtrakulnonth A, Pornrunangwong S, Marnrim N, Kaneko K, Ogawa M: Salmonella in broiler chickens in Thailand with special reference to contamination of retail meat with Salmonella enteritidis. J Vet Med Sci 1998, 60:1233-1236.

4. Gast RK, Guraya R, Guard-Bouldin J, Holt PS, Moore RW: Colonization of specific regions of the reproductive tract and deposition at different locations inside eggs laid by hens infected with Salmonella enteritidis or Salmonella heidelberg. Avian Dis 2007, 51:40-44.

5. Gast RK, Guraya R, Guard-Bouldin J, Holt PS: In vitro penetration of egg yolks by Salmonella Enteritidis and Salmonella Heidelberg strains during thirty-six-hour ambient temperature storage. Poult Sci 2007, 86:1431-1435.

6. Phan TT, Khai LT, Ogasawara N, Tam NT, Okatani AT, Akiba M, Hayashidani H: Contamination of Salmonella in retail meats and shrimps in the Mekong Delta, Vietnam. J Food Prot 2005, 68:1077-1080.

7. Yu CY, Chou SJ, Yeh CM, Chao MR, Huang KC, Chang YF, Chiou CS, Weill FX, Chiu CH, Chu CH, Chu C: Prevalence and characterization of multidrug-resistant (type ACSSUT) Salmonella enterica serovar Typhimurium strains in isolates from four gosling farms and a hatchery farm. J Clin Microbiol 2008, 46:522-526.

8. Yu CY, Chu C, Chou SJ, Chao MR, Yeh CM, Lo DY, Su YC, Horng YM, Weng BC, Tsay JG, Huang KC: Comparison of the association of age with the infection of Salmonella and Salmonella enterica serovar Typhimurium in Pekin ducks and Roman geese. Poult Sci 2008, 87:1544-1549.

9. Limawongpranee S, Hayashidani H, Okatani AT, Ono K, Hirota C, Kaneko K Ogawa M: Prevalence and persistence of Salmonella in broiler chicken flocks. J Vet Med Sci 1999, 61:255-259.

10. Snow LC, Davies RH, Christiansen KH, Carrique-Mas JJ, Wales AD, O'Connor JL, Cook AJ, Evans SJ: Survey of the prevalence of Salmonella species on commercial laying farms in the United Kingdom. Vet Rec 2007, 161:471-476. 
11. Hacking WC, Mitchell WR, Carlson HC: Sources of Salmonellae in broiler chickens in Ontario. Can J Comp Med 1978, 42:392-399.

12. Rigby CE, Pettit JR, Baker MF, Bentley AH, Salomons MO, Lior H: Sources of Salmonellae in an uninfected commercially-processed broiler flock. Can J Comp Med 1980, 44:267-274.

13. Rigby CE, Pettit JR, Baker MF, Bentley AH, Salomons MO, Lior H: Flock infection and transport as sources of Salmonellae in broiler chickens and carcasses. Can J Comp Med 1980, 44:328-337.

14. Wales A, Breslin M, Carter B, Sayers R, Davies R: A longitudinal study of environmental Salmonella contamination in caged and free-range layer flocks. Avian Pathol 2007, 36:187-197.

15. Li X, Payne JB, Santos FB, Levine JF, Anderson KE, Sheldon BW: Salmonella populations and prevalence in layer feces from commercial high-rise houses and characterization of the Salmonella isolates by serotyping, antibiotic resistance analysis, and pulsed field gel electrophoresis. Poult Sci 2007, 86:591-597.

16. Capita R, Alonso-Calleja C, Prieto M: Prevalence of Salmonella enterica serovars and genovars from chicken carcasses in slaughterhouses in Spain. J Appl Microbiol 2007, 103:1366-1375.

17. Vaeteewootacharn K, Sutra S, Vaeteewootacharn S, Sithigon D, Jamjane O, Chomvarin C, Hahnvajanawong C, Thongskulpanich N, Thaewnongiew K: Salmonellosis and the food chain in Khon Kaen, northeastern Thailand. Southeast Asian J Trop Med Public Health 2005, 36:123-129.

18. Chiu CH, Su LH, Chu CH, Wang MH, Yeh CM, Weill FX, Chu C: Detection of Multidrug-Resistant Salmonella enterica Serovar Typhimurium Phage Types DT102, DT104, and U302 by Multiplex PCR. J Clin Microbiol 2006, 44:2354-2358

19. De La Torre E, Zapata D, Tello M, Mejía W, Frías N, García-Peña FJ, Mateu EM, Torre E: Several Salmonella enterica subsp. enterica serotype 4,5,12:i: phage types isolated from swine samples originate from serotype Typhimurium DT U302. J Clin Microbiol 2003, 41:2395-2400

20. McQuiston JR, Parrenas R, Ortiz-Rivera M, Gheesling L, Brenner F, Fields PI: Sequencing and comparative analysis of flagellin genes flic, fljB, and flpA from Salmonella. J Clin Microbiol 2004, 42:1923-1932.

21. Mortimer CK, Peters TM, Gharbia SE, Logan JM, Arnold C: Towards the development of a DNA-sequence based approach to serotyping of Salmonella enterica. BMC Microbiol 2004, 4:31.

22. Yoshida C, Franklin K, Konczy P, McQuiston JR, Fields PI, Nash JH, Taboada EN, Rahn K: Methodologies towards the development of an oligonucleotide microarray for determination of Salmonella serotypes. J Microbiol Methods 2007, 70:261-271.

23. Cardinale E, Gros-Claude JDP Rivoal K, Rose V, Tall F, Mead GC, Salvat G: Epidemiological analysis of Salmonella enterica ssp. enterica serovars Hadar, Brancaster and Enteritidis from humans and broiler chickens in Senegal using pulsed-field gel electrophoresis and antibiotic susceptibility. J Appl Microbiol 2005, 99:968-977.

24. Gaul SB, Wedel S, Erdman MM, Harris DJ, Harris IT, Ferris KE, Hoffman I: Use of pulsed-field gel electrophoresis of conserved Xbal fragments for identification of swine Salmonella serotypes. J Clin Microbiol 2007, 45:472-476.

25. Murase T, Senjyu K, Maeda T, Tanaka M, Sakae H, Matsumoto Y, Kaneda Y, Ito T, Otsuki K: Monitoring of chicken houses and an attached eggprocessing facility in a laying farm for Salmonella contamination between 1994 and 1998. J Food Prot 2001, 64:1912-1916.

26. Pieskus J, Milius J, Michalskiene I, Zagrebneviene G: The distribution of Salmonella serovars in chicken and humans in Lithuania. J Vet Med A Physiol Pathol Clin Med 2006, 53:12-16.

27. van Duijkeren E, Wannet WJB, Houwers DJ, van Pelt W: Serotype and phage type distribution of Salmonella strains isolated from humans, cattle, pigs, and chickens in the Netherlands from 1984 to 2001. J Clin Microbio 2002, 40:3980-3985.

28. Tsai HJ, Hsiang PH: The prevalence and antimicrobial susceptibilities of Salmonella and Campylobacter in duck in Taiwan. J Vet Med Sci 2005, 67:7-13.

29. Chiou CS, Huang JF, Tsai LH, Hsu KM, Liao CS, Chang HL: A simple and low-cost paper-bridged method for Salmonella phase reversal. Diagn Microbiol Infect Dis 2006, 54:315-317.

30. CLSI: Performance standards for antimicrobial disk susceptibility tests; approved standard. Clinical and Laboratory Standards Institute, 9 2006, M2-A9.
31. Kado C, Liu ST: Rapid procedure for detection and isolation of large and small plasmids. J Bacteriol 1981, 174:1365-1373.

32. Chang CC, Lin YH, Chang CF, Yeh KS, Chiu CH, Chu C, Chien MS, Hsu YM, Tsai LS, Chiou CS: Epidemiologic relationship between fluoroquinoloneresistant Salmonella enterica serovar Choleraesuis strains isolated from humans and pigs in Taiwan (1997 to 2002). J Clin Microbiol 2005, 43:2798-2804.

33. Tenover FC, Arbeit RD, Goering RV, Mickelsen PA, Murray BE, Persing DH, Swaminathan B: Interpreting chromosomal DNA restriction patterns produced by pulsed-field gel electrophoresis: criteria for bacterial strain typing. J Clin Microbiol 1995, 33:2233-2239.

34. Guerin MT, Martin SW, Darlington GA, Rajic A: A temporal study of Salmonella serovars in animals in Alberta between 1990 and 2001. Can J Vet Res 2005, 69:88-99.

35. Eaves-Pyles TD, Wong HR, Odoms K, Pyles RB: Salmonella flagellindependent proinflammatory responses are localized to the conserved amino and carboxyl regions of the protein. J Immunol 2001, 167:7009-7016.

36. Gewirtz AT, Simon PO Jr, Schmitt CK, Taylor LJ, Hagedorn CH, O'Brien AD, Neish AS, Madara JL: Salmonella typhimurium translocates flagellin across intestinal epithelia, inducing a proinflammatory response. J Clin Invest 2001, 07:99-109

37. Zeng H, Carlson AQ, Guo Y, Yu Y, Collier-Hyams LS, Madara JL, Gewirtz AT, Neish AS: Flagellin is the major proinflammatory determinant of enteropathogenic Salmonella. J Immunol 2003, 171:3668-74.

38. Tallant T, Deb A, Kar N, Lupica J, de Veer MJ, DiDonato JA: Flagellin acting via TLR5 is the major activator of key signaling pathways leading to NF$\kappa \mathrm{B}$ and proinflammatory gene program activation in intestinal epithelial cells. BMC Microbiol 2004, 4:33.

39. Iqbal M, Philbin VJ, Withanage GSK, Wigley P, Beal RK, Goodchild MJ, Barrow P, McConnell I, Maskell DJ, Young J, Bumstead N, Boyd Y, Adrian L, Smith AL: Identification and functional characterization of chicken Tolllike receptor 5 reveals a fundamental role in the biology of infection with Salmonella enterica Serovar Typhimurium. Infect Immun 2005, 73:2344-2350.

40. Andersen-Nissen E, Smith KD, Strobe KL, Barrett SLR, Cookson BT, Logan SM, Aderem A: Evasion of Toll-like receptor 5 by flagellated bacteria. Proc Natl Acad Sci USA 2005, 102:9247-9252.

41. Beal RK, Powers C, Wigley P, Barrow PA, Kaiser P, Smith AL: A strong antigen-specific T-cell response is associated with age and genetically dependent resistance to avian enteric salmonellosis. Infect Immun 2005, 73:7509-7516.

42. Beal RK, Powers C, Davison TF, Barrow PA, Smith AL: Clearance of enteric Salmonella enterica serovar Typhimurium in chickens is independent of B-cell function. Infect Immun 2006, 74:1442-1444.

43. Chao MR, Hsien CH, Yeh CM, Chou SJ, Chu C, Su YC, Yu CY: Assessing the prevalence of Salmonella enterica in poultry hatcheries by using hatched eggshell membranes. Poult Sc 2007, 86:1651-1655.

44. Angkititrakul S, Chomvarin C, Chaita T, Kanistanon K, Waethwutajarn S: Epidemiology of antimicrobial resistance in Salmonella isolated from pork, chicken meat and humans in Thailand. Southeast Asian J Trop Med Public Health 2005, 36:1510-1515.

45. Liebana E, Garcia-Migura L, Breslin MF, Davies RH, Woodward MJ: Diversity of strains of Salmonella enterica serotype enteritidis from English poultry farms assessed by multiple genetic fingerprinting. J Clin Microbiol 2001, 39:154-161.

46. Chen S, Zhao S, White DJ, Schroeder CM, Lu R, Yang H, McDermott PF, Ayers S, Meng J: Characterization of multiple-antimicrobial-resistant Salmonella serovars isolated from retail meats. Appl Environ Microbiol 2004, 70:1-7.

47. White DG, Zhao S, Sudler R, Ayers $S$, Friedman S, Chen S, McDermott PF McDermott $S$, Wagner DD, Meng J: The isolation of antibiotic-resistant Salmonella from retail ground meats. N Engl I Med 2001, 345:1147-1154.

48. Bywater $R$, Deluyker $H$, Deroover $E$, de Jong $A$, Marion $H$, McConville $M$, Rowan T, Shryock T, Shuster D, Thomas V, Vallé M, Walters J: A European survey of antimicrobial susceptibility among zoonotic and commensal bacteria isolated from food-producing animals. J Antimicrob Chemother 2004, 54:744-754.

49. Boyd D, Cloeckaert A, Chaslus-Dancla E, Mulvey MR: Characterization of variant Salmonella genomic island 1 multidrug resistance regions from 
serovars Typhimurium DT104 and Agona. Antimicrob Agents Chemother 2002, 46:1714-22.

50. Levings RS, Djordjevic SP, Hall RM: SGI2, a relative of Salmonella genomic island SGI1 with an independent origin. Antimicrob Agents Chemother 2008, 52:2529-37.

51. Havlickova H, Hradecka H, Bernardyova I, Rychlik I: Distribution of integrons and SGI1 among antibiotic-resistant Salmonella enterica isolates of animal origin. Vet Microbiol 2009, 33:193-8.

52. Chen S, Cui S, McDermott PF, Zhao S, White DG, Paulsen I, Meng J: Contribution of target gene mutations and efflux to decreased susceptibility of Salmonella enterica serovar Typhimurium to fluoroquinolones and other antimicrobials. Antimicrob Agents Chemother 2007, 51:535-542.

doi:10.1186/1471-2180-10-86

Cite this article as: Chiu et al:: Characterization of 13 multi-drug

resistant Salmonella serovars from different broiler chickens associated with those of human isolates. BMC Microbiology 2010 10:86.

\section{Submit your next manuscript to BioMed Central} and take full advantage of:

- Convenient online submission

- Thorough peer review

- No space constraints or color figure charges

- Immediate publication on acceptance

- Inclusion in PubMed, CAS, Scopus and Google Scholar

- Research which is freely available for redistribution

Submit your manuscript at www.biomedcentral.com/submit 